\title{
O motivo dos três caminhos em um desenho devocional popular luterano e suíço de 1800: uma leitura warburgiana
}

\author{
The motive of the three paths in a popular Lutheran and Swiss \\ devotional drawing of 1800: a Warburgian reading
}

Helmut Renders *

\begin{abstract}
Resumo
Este artigo propõe a leitura de representações da cultura visual religiosa com fins devocionais a partir dos conceitos do Nachleben e dos Pathosformeln de Aby Warburg. O objeto de pesquisa é um desenho suíço com os motivos dos três caminhos e com o título "Estreita é a porta, e apertado, o caminho que leva à vida, e poucos há que a encontrem". Depois de uma reflexão sobre a tradução e compreensão subjacente de Nachleben, aplica-se o conceito tanto às narrativas visuais (Crucifixo, Levante de Serpente, Nova Jerusalém, cidade da Vaidade, Paraíso, Boca do Inferno, dois (três) caminhos) como textuais e metafóricas (citações de textos bíblicos e hinos). Conclui-se que se pode falar de um Nachleben no sentido duplo - tanto de metáforas bíblicas (ou da Antiguidade) transformadas em imagens como de ênfases luteranas a partir da contribuição de Lucas Cranach, o Velho - e que o conceito de Pathosformeln articula bem o aspecto performativo e, ao mesmo tempo, educativo e apelativo do gênero da arte sagra devocional.
\end{abstract}

Palavras-chave: Linguagens religiosas. Cultura visual religiosa. Aby Warburg. Nachleben. Pathosformeln.

\begin{abstract}
This article proposes the reading of representations of the religious visual culture with devotional ends from Aby War-burg's concepts Nachleben and Pathosformeln. The research object is a Swiss drawing with the motifs of the three paths and the title "Narrow is the gate, and narrow, the road that leads to life, and few there are that find it." After a reflection on the translation and subjacent understanding of Nachleben applies whether the concept to both visual narratives (Crucifix, Serpent's Rise, New Jerusalem, Vanity City, Paradise, Hellmouth, two (three) paths) as textual and metaphorical (quotations from biblical texts and hymns) of the work. It may be concluded that one can speak of a Nachleben in the double sense - both of biblical (or antiquity) metaphors transformed into images and of Lutheran emphases from the contribution of the older Lucas Cranach - and that the concept of Pathosformeln articulates well the performative and at the same time educational and appealing aspect of the sacred devotional art genre.
\end{abstract}

Keywords: Religious languages. Religious visual culture. Aby Warburg. Nachleben. Pathosformeln.

Artigo submetido em 27 de agosto de 2018 e aprovado em 17 de maio de 2021.

* Doutor em Ciências da Religião pela UMESP. Professor da UMESP. País de origem: Alemanha. E-mail: helmut.renders@metodista.br 


\section{Introdução ${ }^{1}$}

Segue um estudo da representação da cultura visual religiosa da Europa Central partindo de uma análise da sua composição e de suas principais narrativas visuais e textuais e de suas citações e referências. Partimos de uma proposta metodológica de Aby M. Warburg de interpretar obras a partir dos conceitos do Nachleben de motivos que compõem uma imagem e sua interpretação como Pathosformeln.2

Para tanto, precisamos, primeiro, esclarecer seus significados. No sentido mais restrito, Aby Warburg descreve como Nachleben a complexa relação entre a iconografia pré-cristã, suas metáforas imagéticas, alegorias e narrativas visuais, e a arte visual renascentista, que apresentam as traduções encontradas do conceito de problemas significativas. Já Pathosformeln indica o aspecto performativo de um motivo, que se aproxima da compreensão de Horst Bredekamp (2015) do "ato icônico" ou de David Morgan (2014) da "agência de objetos”. As traduções de Nachleben encontradas na literatura inglesa e portuguesa não satisfazem completamente, nem as formas mais literais "sobrevivência" (survival), vida depois da morte (afterlife) - nem as formas mais interpretativas "renascimentos" (rebirth), ou "lembranças de coisas do passado" (rememberance of things past). Assim comenta também Giorgio Agamben: "O termo alemão Nachleben não significa propriamente 'renascimento', como foi muitas vezes traduzido, nem 'sobrevivência'. Ele implica a ideia daquela continuidade da herança pagã que, para Warburg, era essencial." (AGAMBEN, 1999, p. 95).

Quanto ao significado original, propomos uma nova abordagem. Parecenos que a palavra Nachleben acompanha as estruturas significantes de outras palavras como Nachkommen ou Nachbeben de alegorias, metáforas, formas e motivos visuais. As três palavras são verbos substantivados, ou seja, seu tom está na dinâmica, no movimento; portanto, não se trata de um substantivo

\footnotetext{
${ }^{1}$ Agradeço o Prof. Dr. Vitor Chaves de Souza e o doutorando Altierez Sebastiao dos Santos. Eles leram o texto antes da sua submissão e fizeram importantes comentários e sugestões que contribuíram para a versão final do texto.

${ }^{2} \mathrm{~A}$ investigação apresentada a seguir faz parte do projeto de pesquisa "Cultura visual evangélica: o surgimento". O desenho de lápis, colorido à mão com tinta aquarela, é com alta probabilidade uma cópia inspirada em uma gravura ou xilogravura, talvez de origem alemã, talvez francesa. De fato, conhece-se um conjunto de cerca de vinte diferentes xilogravuras e litografias franceses, franco-alemãs e alemãs parecidas em muitos detalhes. Entretanto, enquanto essas outras obras populares não são mais antigas do que 1824, o desenho aqui apresentado é de cerca de 1800 . Com isso ele antecipa os outros por quase uma geração. Projeto Regular FAPESP Processo 2015/13737-7, vigência 2017-2019.
} 
clássico com sua tendência mais conceitual técnica e abstrata. Nachleben composto, literalmente, pelo verbo "viver" no infinitivo e "depois" como conjunção no lugar de prefixo - foca no aspecto vital, essencial ou significativo de um motivo (visual), de uma metáfora ou de uma alegoria. Nachleben quer dizer que um motivo antigo se mantém também fora e além do seu habitat original, algo fecundante, inspirador e significante. Nachkommen são aqueles que vêm depois, descendentes de algo ou alguém que nos faz pensar de imediato tanto sobre semelhança como sobre a diferença, tradição e releitura. Nachbeben são aqueles tremores menores que seguem terremotos maiores, ou seja, que somente existem por causa deles sem ser uma cópia exata quanto à forma ou à intensidade.

Tudo isso fica mais claro quando se introduz ainda uma segunda percepção de Warburg, as chamadas fórmulas de paixão3 (Pathosformeln) que Agamben descreve como "[...] um entrelaçamento indissolúvel de uma carga emocional e uma fórmula iconográfica em que é impossível distinguir entre forma e conteúdo.” (AGAMBEN, 1999, p. 99). O acento de Nachleben não está em "fórmula", mas em "paixão", e "carga emocional” não está no conceito, mas no impulso. Não se trata de uma repetição formal de uma ou mais formas no sentido de uma cópia, mas, de um aspecto de um motivo que o manteve impactante e cativante. Rodrigo Hipólito e Fabiana Pedroni (2017) citam DidiHuberman:

[...] a relação entre cultura, como elemento artificial no jogo histórico, e vida, como inevitabilidade relacional, aponta para um sentido de vida na Nachleben como uma simultaneidade do jogo de funções (abordagem antropológica), do jogo de formas (abordagem morfológica) e de um jogo de forças (abordagem dinâmica e energética). No primeiro caso, falamos dos processos de dar significado às ações humanas e compreendemos a abordagem antropológica como um sistema que permite também interpretar tais ações em conjunto. No segundo caso, a abordagem morfológica procura dar aparências aos significados (inclusive, ações como aparências), formar um conjunto inteligível de tais aparências e estabelecer uma axiologia que confira valores a tal conjunto. [...] Já no terceiro caso, a abordagem dinâmica e energética nos permite gerar relações entre significados e significados, aparências e aparências, significados e aparências, assim como entre seus conjuntos. Quando compreendemos a simultaneidade desses jogos, seu contínuo movimento e emaranhar de imagens, experiências e ideias, aproximamo-nos da Leben das imagens. (HIPÓLITO; PEDRONI, 2017, p. 245).

3 Ás vezes, lê-se também “fórmulas de emoções”. Cf. Leão Serva (2017). 
Entretanto, o empréstimo de Warburg requer mais um esclarecimento. Seguindo uma distinção de Friedrich Wilhelm Nietsche (1780), Warburg vincula Nachleben e Pathosformeln ao ethos dionisíaco pagão em oposição ao ethos apolíneo cristão. José Emilio Burucúa (2003) vai mais longe ainda:

Warburg, acreditava que as formas artísticas objetivavam tais externalizações, que as condensavam em mecanismos sensíveis - o Pathosformeln - capazes de evocar, em um curso oposto ao usual procedimento da memória, os engramas originais e, assim, elevar a memória das experiências primárias da humanidade. (BURUCÚA, 2003, p. 24, tradução nossa). 4

Concordamos com Burcúa que o fenómeno é mais ampla. Já entendemos que Nachleben e Pathosformeln podem descrever da mesma forma aspectos intra-cristãos como a relação entre motivos clássicos do mundo cristão e o cristianismo contemporâneo, especialmente sua aparência na arte devocional e popular religiosa. 5 Isso nos parece ainda mais relevante, quando se trata de narrativas visuais da paixão de Cristo, de cenas do paraíso ou metáforas visuais como a Nova Jerusalém, a porta estreita ou a porta do inferno. Trata-se de motivos literalmente carregados de pathos, ou seja, de paixões, de crises existenciais e, ao mesmo tempo, de sonhos e esperanças.

O objeto investigado é um desenho a lápis colorido de autoria desconhecida que se encontra hoje no Acervo do Museu das Culturas de Basiléia na Suíça, número de acervo VI-61756. Há teorias diversas sobre sua origem, mas suponho que se trata de uma cópia produzida de uma gravura ao redor de 180o. De fato, existem gravuras com muitas similaridades em relação a motivos parciais contidos e à composição geral produzidos inicialmente, na Alsácia uma região bilíngue franco-alemã - e na cidade de Épinal na França; depois na Alemanha, por exemplo, na cidade de Augsburgo, mas, em todos os casos não antes de 1825. Diga-se de passagem, que estas cidades, localizadas no sudeste da França e no sul da Alemanha, não ficam longe da Basileia, localizada no noroeste da Suíça, ou seja, consta até uma circulação interconfessional da

\footnotetext{
${ }_{4}$ Warburg, creía que las formas artísticas objetivaban tales exteriorizaciones, que las condensaban en mecanismos sensibles - los Pathosformeln - aptos para evocar, en un discurrir opuesto al del procedimiento habitual de la memoria, los engramas originales, y suscitar con ello el recuerdo de experiencias primarias de la humanidad.

${ }_{5}^{5}$ Somente uma interpretação do cristianismo como essencialmente um sistema doutrinário ou como instituição pode ser reduzida a um foco na ordem, racionalidade e harmonia intelectual, equivalente àquilo que representa o Deus Apolo. Já a religião como experiência e prática mística [popular] cheia de disposição, espontaneidade e fascínio pelo êxtase religioso encontra mais seu modelo no semideus Dionísio. Seguimos aqui exemplos de aplicação como de Serva (2013) e das reflexões de Becker (2015).
} 
imagem entre territórios católicos, luteranos e reformados. Uma gravura desse tipo criado antes de 1825, inclusive antes de 1800 , entretanto, ainda não foi localizada. Quanto a alguns motivos do desenho, particularmente não encontrados nas gravuras mencionadas acima, exploraremos a possiblidade de uma dependência da iconografia de uma série de obras criadas por Lucas Cranach, o velho, conhecidos pelos nomes Lei e Evangelho (1530) ou Lei e Graça (1529).

\section{Nachleben e Pathosformeln nas narrativas visuais}

Para facilitar a orientação na imagem organizamos o texto segundo seus principais motivos (figura 1) e propomos uma leitura da sua composição (figura 2). 6

Figura 1: A porta é apertada, o caminho é estreito: divisão em seções

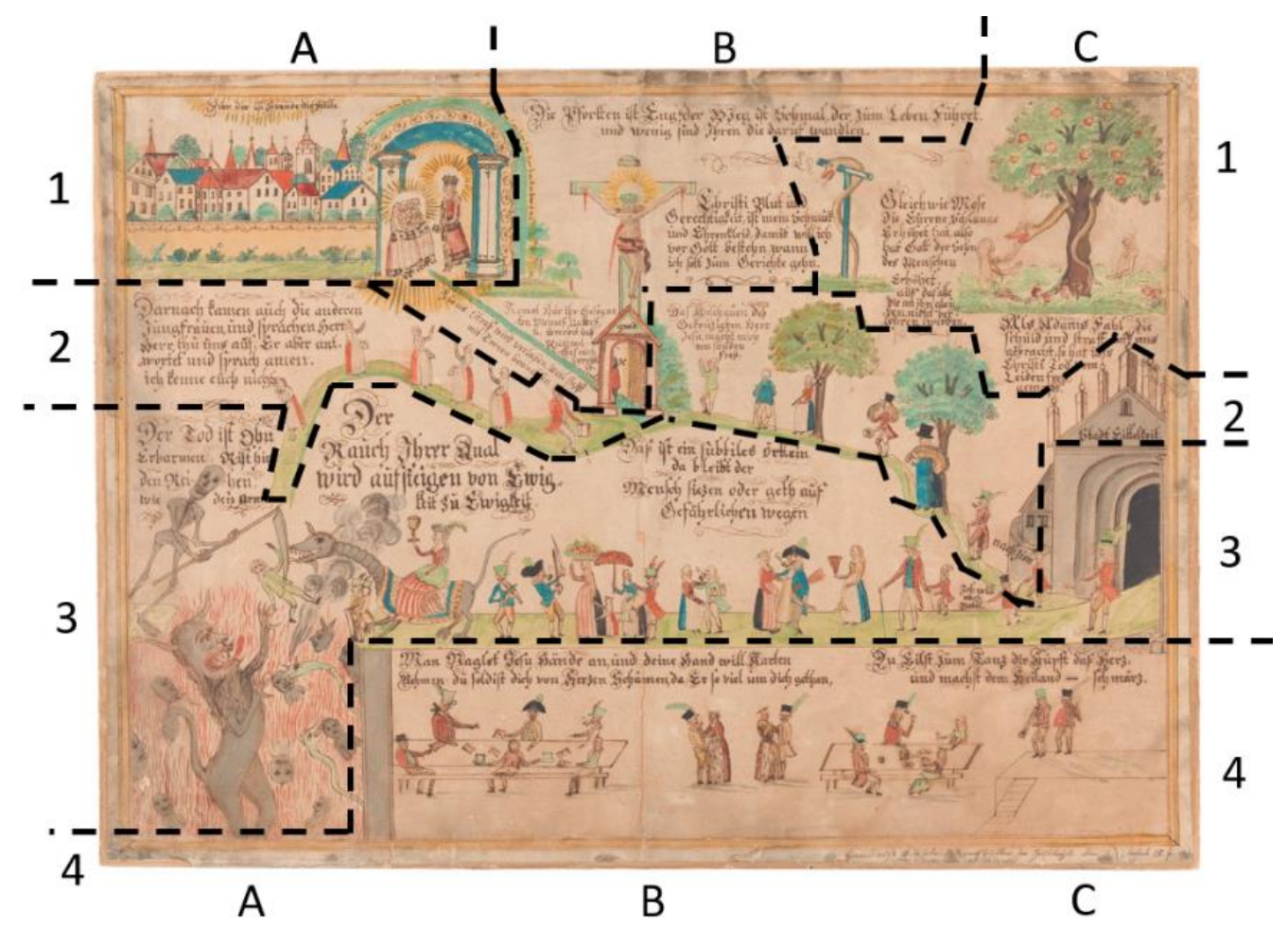

Fonte: Museu das Culturas, Basiléia, Suíça, Acervo gráfico, número VI-61756, [1800].

\footnotetext{
${ }^{6}$ Agradeço ao Museu das Culturas na Basiléia, Suíça, o acesso a esta obra e o direito de publicar este desenho na íntegra e em partes. Os deveres e direitos foram estabelecidos pelo contrato de direito de reprodução da imagem 17//56 número de referência 10094 VNR-17-56. A criação da média usada foi financiada pelo Programa PROEX da CAPES, Processo 2015.13737-7. O acesso ao acervo foi financiado com verbas FAPESP, Reunião no Exterior, Processo 2016.24674-9.
} 
A divisão da obra em base dos seus motivos principais segue uma lógica temática que une tanto os aspectos visuais como textuais. Por causa disso, há seções menores como, por exemplo, a seção $1 \mathrm{~A}, 1 \mathrm{~B}$ ou $1 \mathrm{C}$ e maiores, como no caso das seções $4 \mathrm{BC}, 3 \mathrm{ABC}$ ou $2 \mathrm{AB}$.

Figura 2: A porta é apertada, o caminho é estreito: lugares e simbólicos e símbolos religiosos

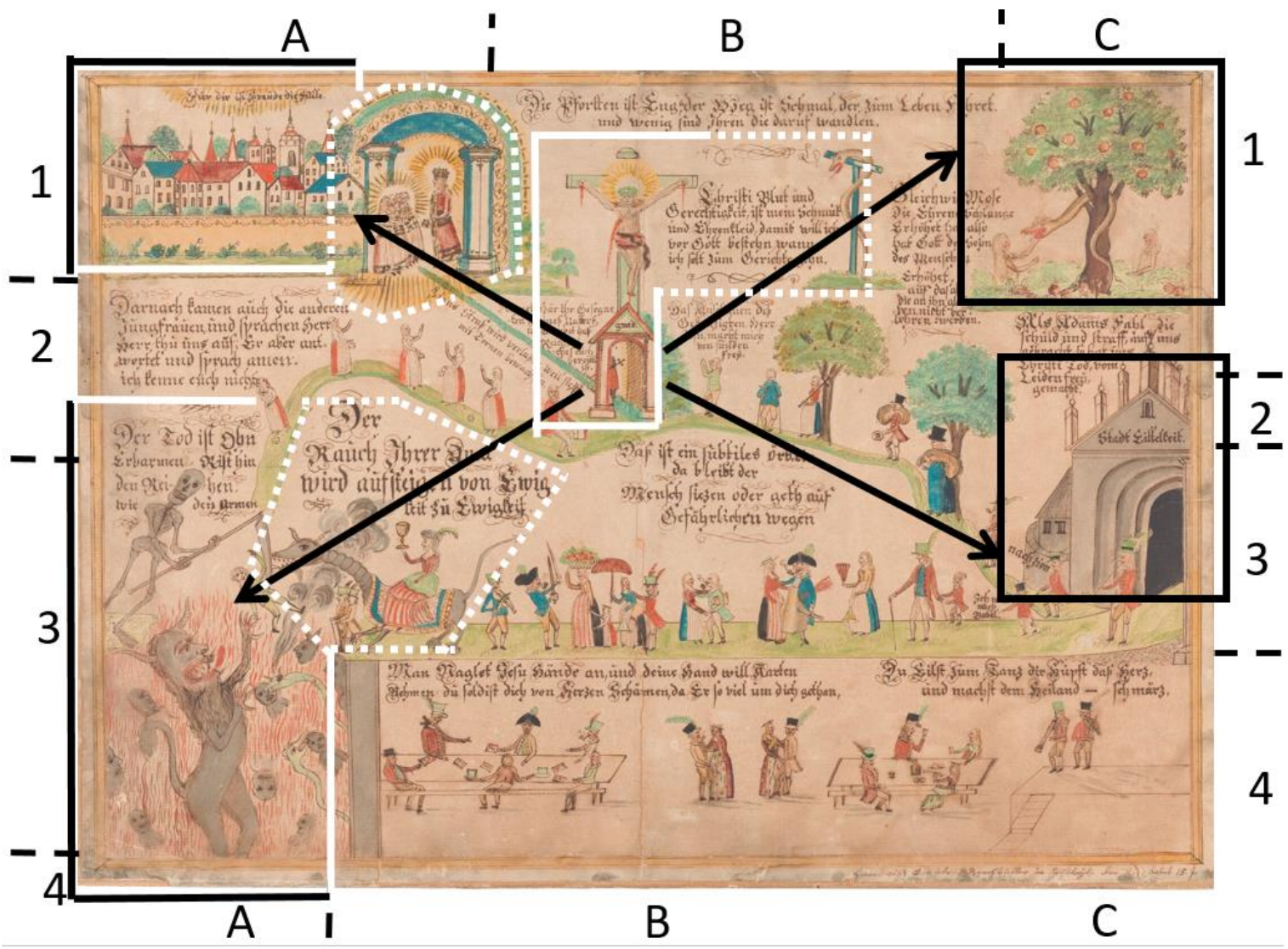

Fonte: Museu das Culturas, Basiléia, Suíça, Acervo gráfico, número VI-61756, [1800].

Os motivos principais da obra (figura 2) são seis:

Nos quatro "cantos" encontram-se quatro lugares simbólicos "opostos": A Nova Jerusalém (seção 1A) e a cidade da vaidade (seção 2 e 3C); o paraíso (seção $1 \mathrm{C}$ ) e [a boca d]o inferno (seção 3A);

- Ao centro temático pertencem dois símbolos religiosos, crucifixo e serpente (seção 1B). 
Figura 3: A porta é apertada, o caminho é estreito: Caminhos alternativos

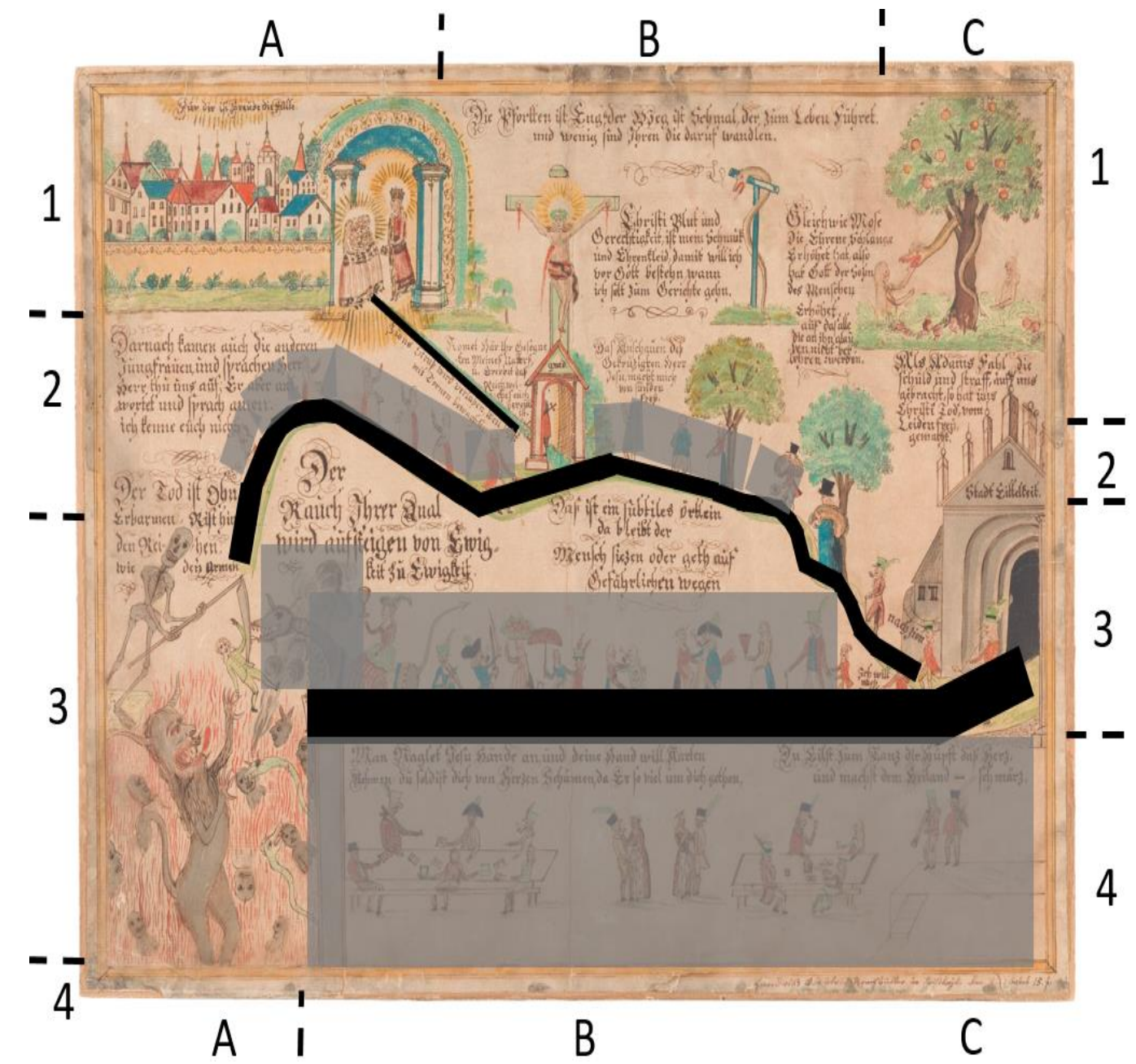

Fonte: Museu das Culturas, Basiléia, Suíça, Acervo gráfico, número VI-61756, [1800].

Com a exceção do paraíso, os lugares simbólicos são ligados por três caminhos, aqui mencionados da forma como eles aparecem no desenho de cima para baixo (figura 3):

a) Um caminho muito estreito que, literalmente, passa pela cruz à Nova Jerusalém (seção 1B);

b) O caminho estreito que passa somente por perto da cruz e de lá para a morte (seções $2 \mathrm{~A}-\mathrm{C}$ ),

c) O caminho largo que leva diretamente da cidade da vaidade ao inferno (seções 3A-C). 
O segundo e terceiro caminho, junto aos motivos do inferno, da cidade da vaidade, e as pessoas que se movem nesses caminhos, ocupam mais do que a metade do espaço do desenho. Como todo, representa esse desenho uma cartografia dos caminhos da salvação ou da perdição. Na representação dos três caminhos (figura 3), marcamos ainda com a cor cinza os espaços ocupados pelas figuras relacionadas com cada um dos caminhos.

Anota-se que no Caminho estreito (seção 1B) não se encontra um ser humano sequer, somente um grupo de recém-chegados ao portal da Nova Jerusalém. A distribuição dos motivos define também o motivo que o/a leitor/a comum primeiro observa: o motivo da Nova Jerusalém na parte superior esquerda (1A). Logo se revela a ele/a o objetivo da obra: chegar à cidade celestial pela escolha do caminho certo. Essa compreensão é ampliada pelo versículo que serve com o título do desenho: “O portão é apertado, / a estrada é estreita, / que leva à vida, / e há poucos / que caminham nele. " (MUSEU DAS CULTURAS, VI61756, tradução nossa). 7 O foco do versículo está na perseverança, na capacidade de se manter no caminho (darauf wandeln). Quem segue o caminho que leva à Nova Jerusalém ao contrário até o seu início, encontra duas afirmações que revelam dois projetos de vida distintos: "Eu quero ir para Sião" (secção C2, passagem textual 2.1) e "Eu quero ir para Babel" (na secção B3, passagem textual 4.2).

\subsection{A narrativa dupla visual central: crucifixo e serpente erguida}

Ao lado da importância da narrativa da Nova Jerusalém (figura 8), localiza-se no centro do desenho sua mensagem essencial. Percebe-se a intenção do artista de descrever o destino celestial ou infernal dos/as peregrinos/as a partir da forma como eles/as se relacionam com a mensagem da cruz (B1). Quem passa por ele segue o caminho em direção ao céu (figura 8); quem não passa, vai para a perdição.

\footnotetext{
7 "Díe Pforten ist eng, / der Weg ist schmal, / der zum Leben führet, / und wenige sind ihren, / die darauf wandeln”. No alemão moderno seria "ihrer" a forma correta.
} 


\section{Figura 4: Lucas Cranach, o Velho, Lei e Graça, 1529 $^{8}$}

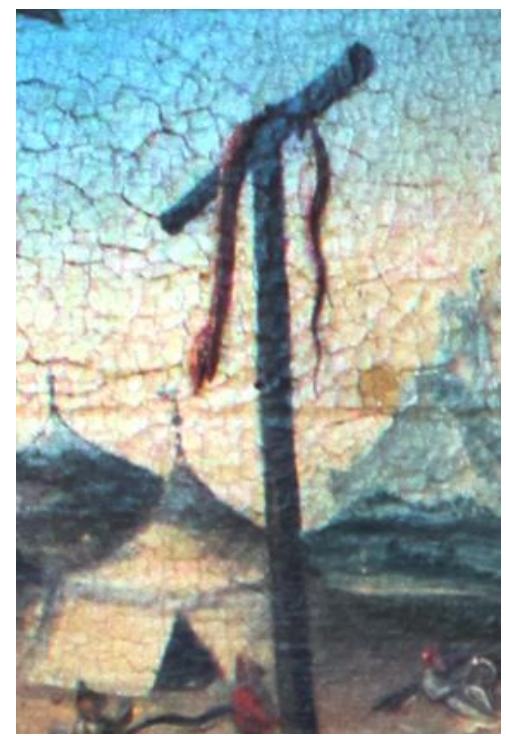

Fonte: (WIKIPÉDIA, 2013).

\section{Figura 5: A porta é apertada, o caminho é estreito (setor C1)9}

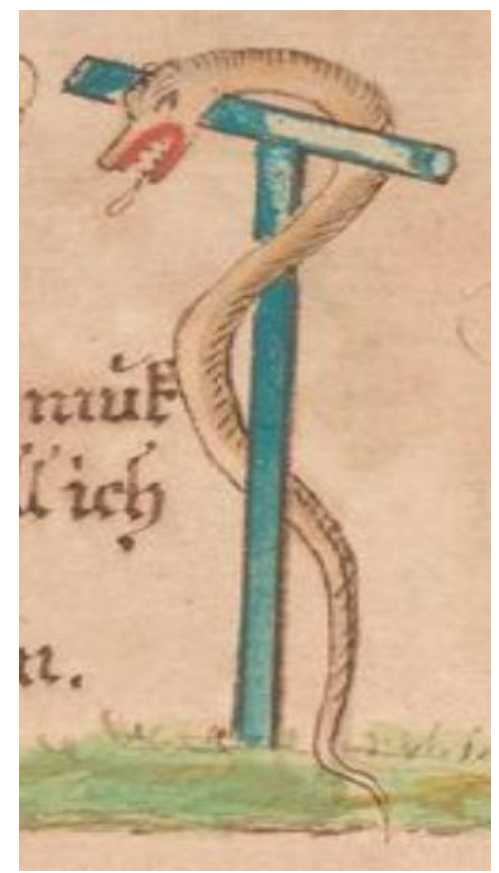

Fonte: Museu das Culturas, Basiléia, Suíça, Acervo gráfico, número VI-61756, [1800].

8 Detalhe "A serpente elevada".

9 Detalhe "A serpente elevada". 
O conjunto de crucifixo mais a serpente erguida (B1) remete a João 3.1417 e apresenta uma interpretação alternativa da morte vicária de Jesus Cristo como sinal do amor de Deus para com o mundo.

Estes conjuntos de motivos, inclusive de Adão e Eva no paraíso (C1), já apareceram nos retábulos luteranos da oficina de Lucas Cranach o mais velho (Schneeberg, 1529) e o mais jovem (Weimar, 1584) ou em Lei e Evangelho (1529). Pode-se falar, então, já do início, de uma citação de uma narrativa luterana visual clássica. Na história da teologia é um motivo-chave desde Abelardo (1079-1142 d.C.), que escolheu João 3.14-17 como referência-chave da sua teologia da cruz em oposição a Anselmo da Cantuária (1033-1109 d.C.).

Figura 6: Lucas Cranach, o Velho. Lei e Graça, 152910

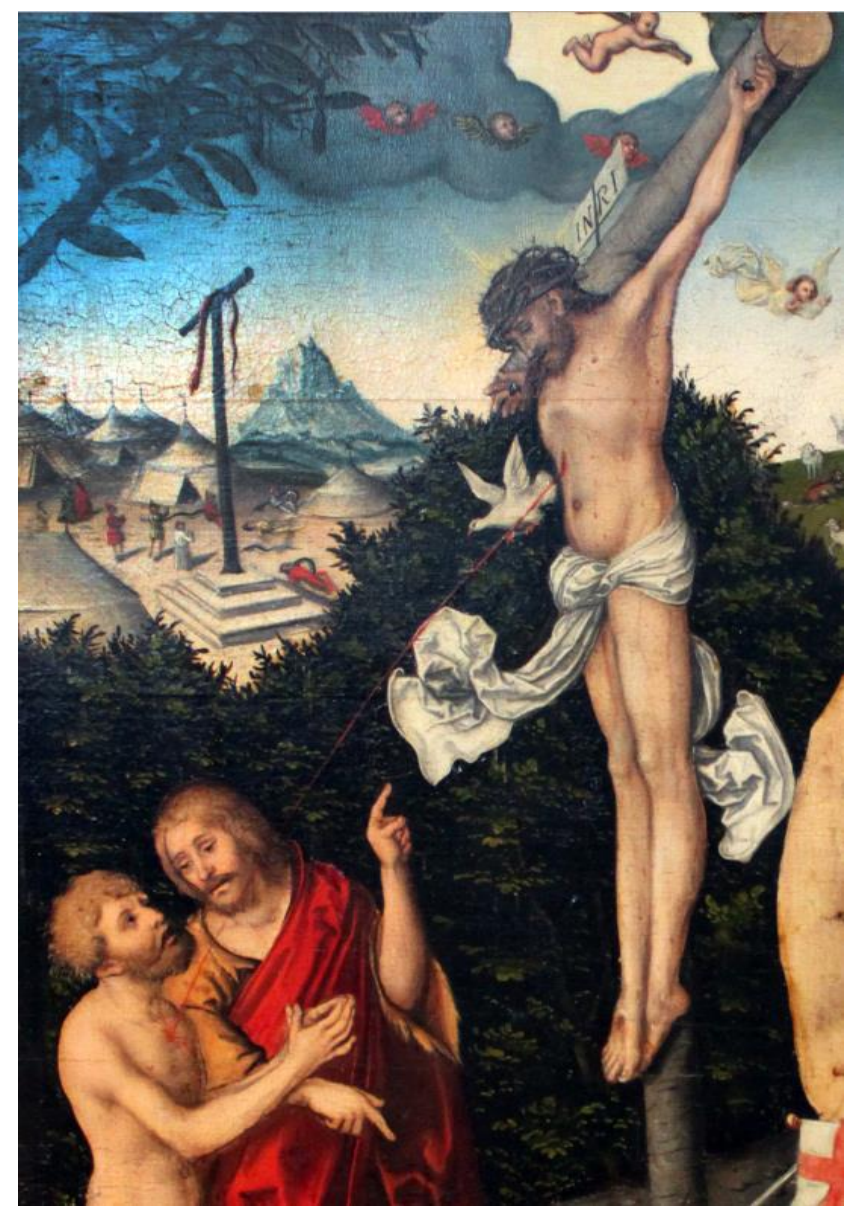

Fonte: (WIKIPÉDIA, 2013).

${ }^{10}$ Detalhe "o sangue vai do lado de Jesus para o coração do pecador arrependido". 


\section{Figura 7: A porta é apertada, o caminho é estreito (setor B1) ${ }^{11}$}

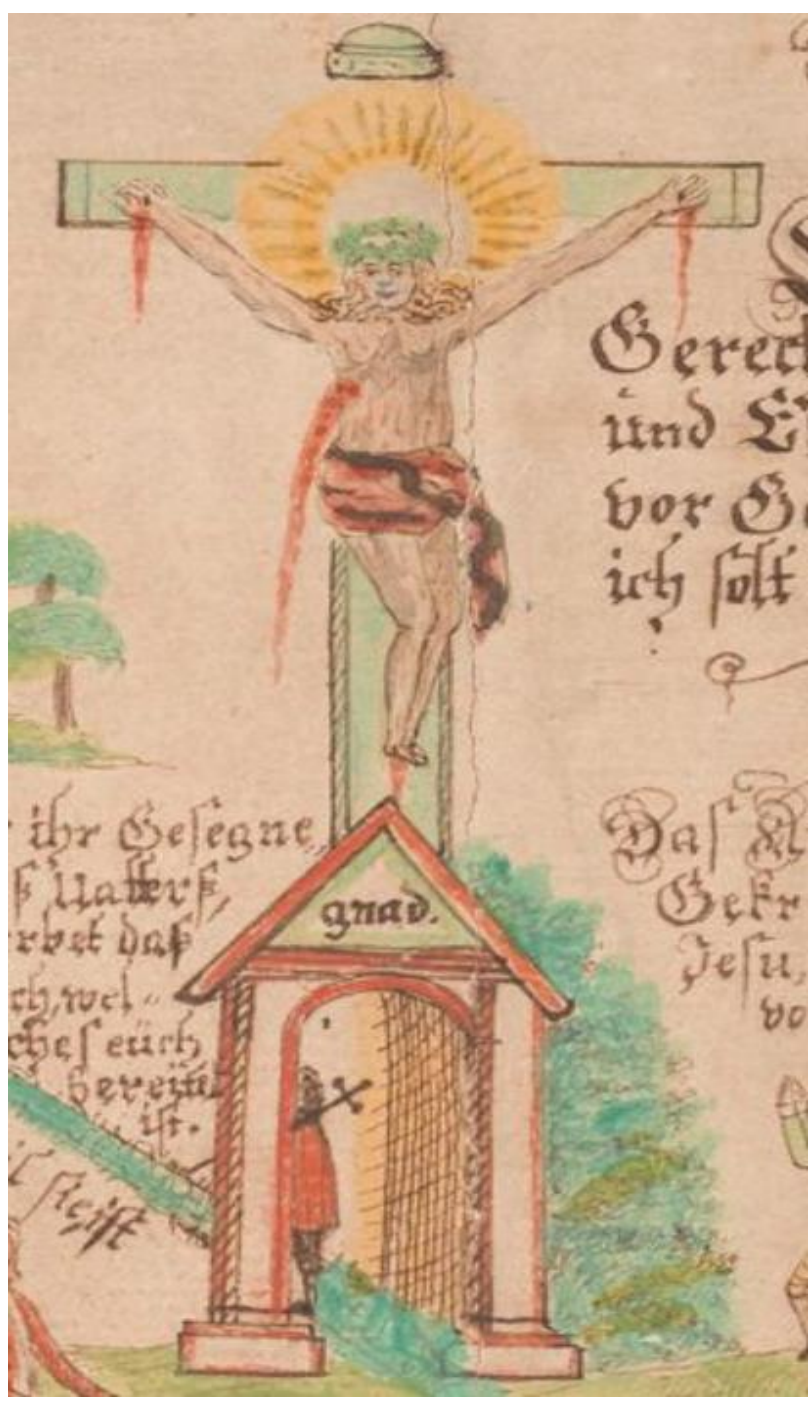

Fonte: Museu das Culturas, Basiléia, Suíça, Acervo gráfico, número VI-61756, [1800].

No século 19, o teólogo luterano Albrecht Ritschl (1822-1889 d.C.) redescobriu Abelardo e sua ênfase em João 3.14-17, mas relacionou isso com a teologia paulina da reconciliação como superação da inimizade humana. Em nossa obra, João 3.14-17 aparece como narrativa textual: "Como Moisés levantou a serpente de ferro, assim levanto Deus o Filho do Homem, para que todos/as o que nele creem, não sejam perdidos”. ${ }^{12}$ Entretanto, o desenho foi criado setenta anos antes da respectiva publicação de Ritschl.

\footnotetext{
${ }^{11}$ Detalhe "crucifixo".

12 "Gleichwie Mose die eherne Schlange erhöhet hat, also hat Gott der - correto seria hoje "den" - Sohn des Menschen erhöhet, auf das alle die an ihn glauben, nicht verloren werden“.
} 
O crucifixo (Setor B1, figura 7) lembra o de Cranach (figura 6). No topo da porta estreita lê-se a palavra Gnad, ou seja, graça: o crucificado é sinal da graça de Deus e, ao mesmo tempo, porta pela qual os peregrinos e as peregrinas precisam passar. Repare-se que a ênfase no sangue que sai do lado de Jesus vai nos retábulos de Cranach para o peito ou a cabeça do pecador arrependido ou na cabeça do próprio Lucas Cranach o mais velho, uma ideia que nosso desenho cita de forma sutil, considerando que o sangue que sai do lado do corpo de Jesus parece cair justamente acima da figura que acaba passando pelo portal abaixo da cruz, carregando sua cruz. A ênfase católica em relação ao sangue de Jesus com a eucaristia ou o sacramento é então totalmente omitido.

Isso nos leva à compreensão que $\mathrm{o} / \mathrm{a}$ criador/a desse desenho ou $\mathrm{o} / \mathrm{a}$ criador/a da obra supostamente por ele/a copiada, segue proposionalmente um programa visual luterano estabelecido na primeira fase da Reforma Protestante, nesse caso, da Reforma luterana, isso é, de 260 a 220 anos antes da criação do nosso desenho.

\subsection{As duas narrativas duplas vinculadas: a "Nova Jerusalém" e "a cidade da vaidade" como "O inferno" e "O paraíso"}

\subsubsection{A "Nova Jerusalém" e "a cidade da vaidade"}

Afirmamos anteriormente que o motivo da Nova Jerusalém (figura 8) é aquele que se encontra na "entrada" do desenho. Em outros termos, ao lado do motivo central ele requer uma atenção especial. Ela se apresenta como uma cidade cercada de um muro, as casas com tetos em cores vivas. O motivo da Nova Jerusalém é acompanhado pelo motivo da recepção de quatro mulheres ao Cristo na entrada da cidade. Ao redor das suas cabeças e da cabeça de Cristo, encontram-se raios que sugerem um brilho que aparentemente é uma referência ao halo como sinal da pertença a Deus. A figura de Cristo carrega ainda uma coroa, e sua roupa vermelha lembra a vestimenta de um rei. 
Figura 8: A porta é apertada, o caminho é estreito (setor B1)13

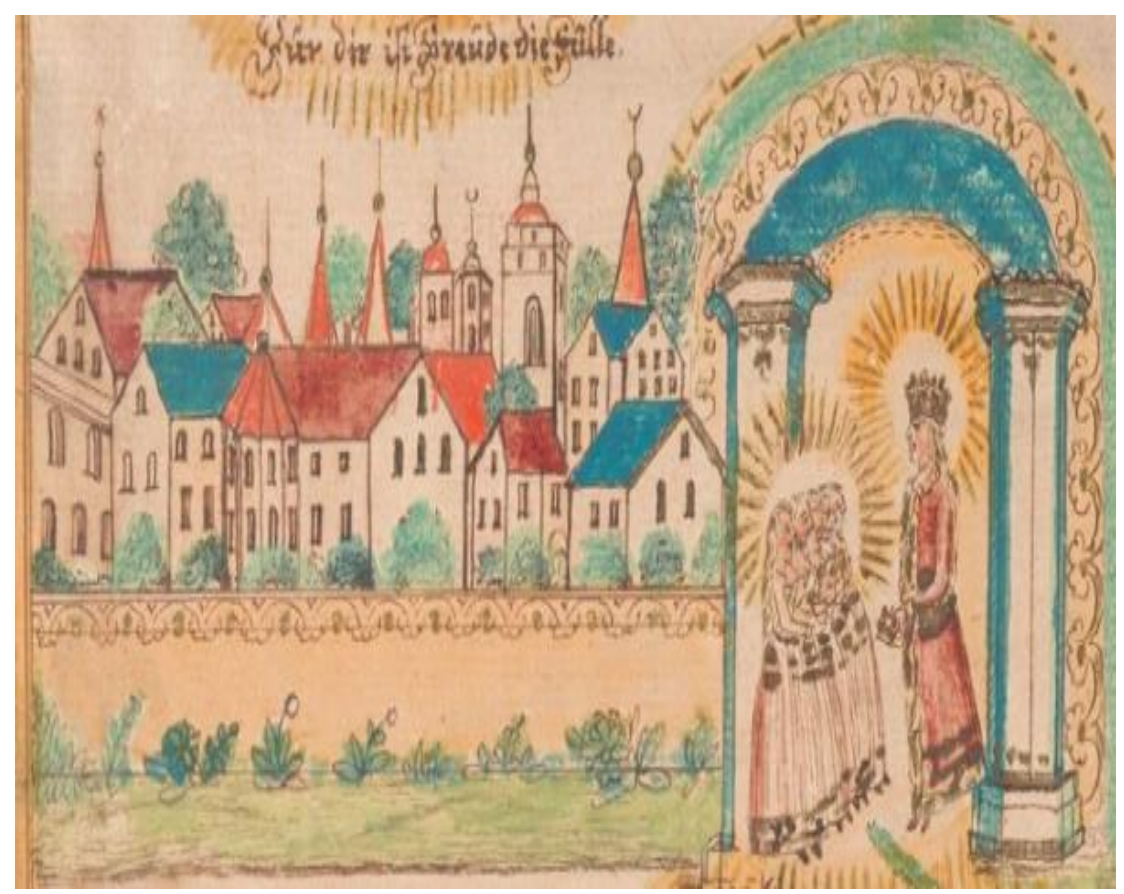

Fonte: Museu das Culturas, Basiléia, Suíça, Acervo gráfico, número VI-61756, [1800].

\section{Figura 9: A porta é apertada, o caminho é estreito (setor B1)14}

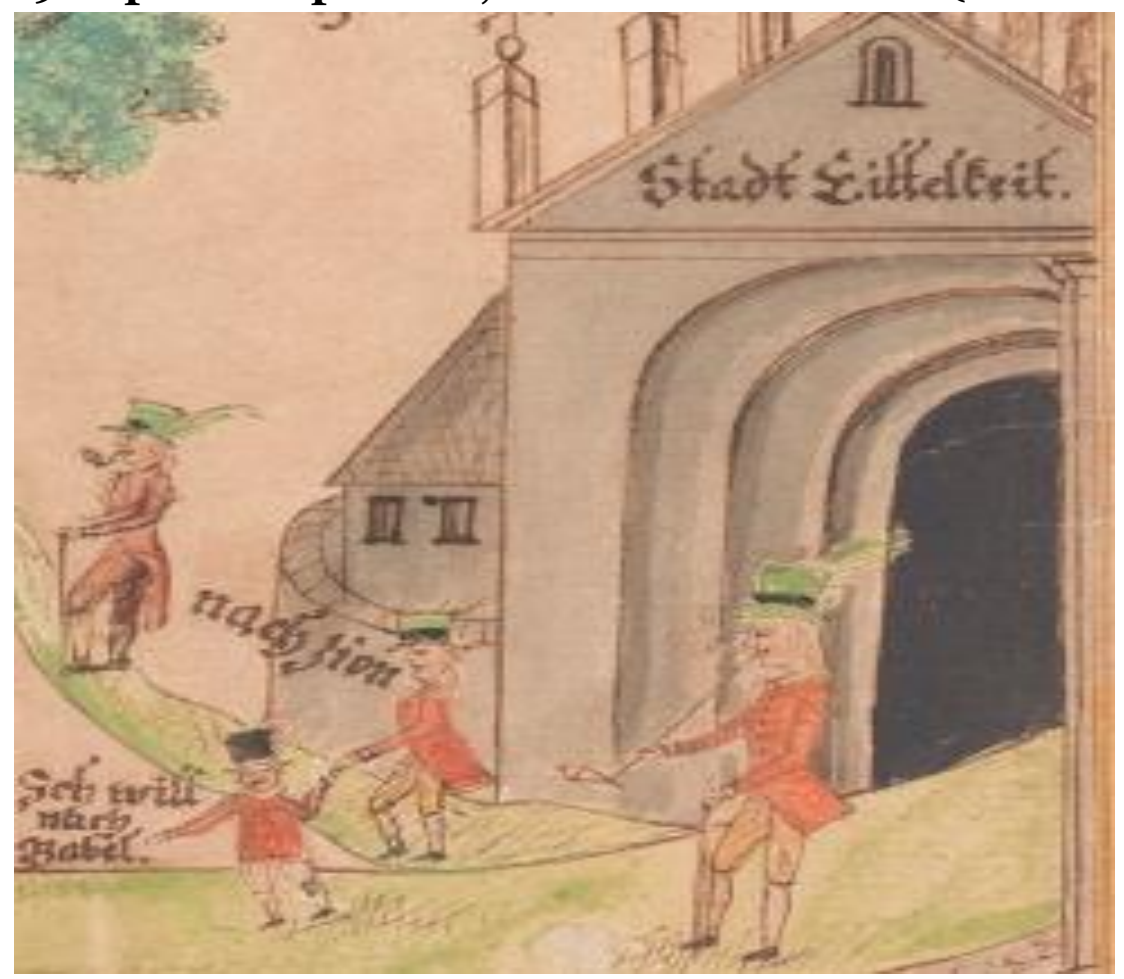

Fonte: Museu das Culturas, Basiléia, Suíça, Acervo gráfico, número VI61756, [1800].

13 Detalhe "Nova Jerusalém".

${ }^{14}$ Detalhe "Cidade da vaidade". 
A imagem oposta a essa viva e colorida cena é um portal (figura 9) pintado na cor cinza $\left(\mathrm{C}_{3}\right)$, que contém na sua parte superior as palavras "Cidade da vaidade" (passagem textual 4.2). O fundo do portal é escuro, e o vazio da cena parece interpretar a "vaidade" do lugar. Perto ou dentro do Portal da Nova Jerusalém, encontram-se, com a exceção de Jesus, somente mulheres. Vemos, perto do portal da cidade da vaidade, somente homens, vestidos com calças até os joelhos, jaquetas vermelhas e chapéus verdes com faixa preta e penacho. Os dois homens maiores fumam cachimbo. Dois deles parecem debater o caminho a tomar. Um diz: "Para Sião"15; o outro: "Eu quero ir para Babel”16.

\subsubsection{O inferno e o paraíso}

No setor A3 encontramos a imagem dupla da boca do inferno com a mulher sentada em um dragão, segurando um cálice (figura 11). O motivo da boca do inferno é antigo e constitui um dos raros exemplares da integração do imaginário normando no imaginário cristão universal (Cf. SCHAPIRO17, 1984, 1987), que aparece por volta do ano 800 (SCHMIDT, 1995). Um exemplo dessa integração é um tympanum do Juízo Final na Igreja de Sainte-Foy, França, Conques, construída entre 1050-1130 d.C. Exemplos da sua importância no imaginário cristão são também a Divina Comédia de Dante Alighieri (12651321), o portão do inferno é o ponto de partida da descida; a obra Otelo de William Shakespeare (1564-1616); a pintura $O$ sonho de Felipe II de 1579 do pintor espanhol El Greco (1541-1614) e a famosa obra La Porte de l'Enfer de François-Auguste-René Rodin (1840-1917). Mais uma vez, encontramos uma semelhança com a obra Lei e Evangelho e diversos retábulos de Cranach.

\footnotetext{
15 "Nach Zion".

16 "Ich will nach Babel".

${ }_{17}$ Meyer Schapiro (1914-1996) era um historiador de arte de abordagem marxista. Entendemos que, ao lado da compreensão mais culturalista de Erwin Panofsky e formalista de Heinrich Wölfflin, esta perspectiva continua tendo a sua importância.
} 


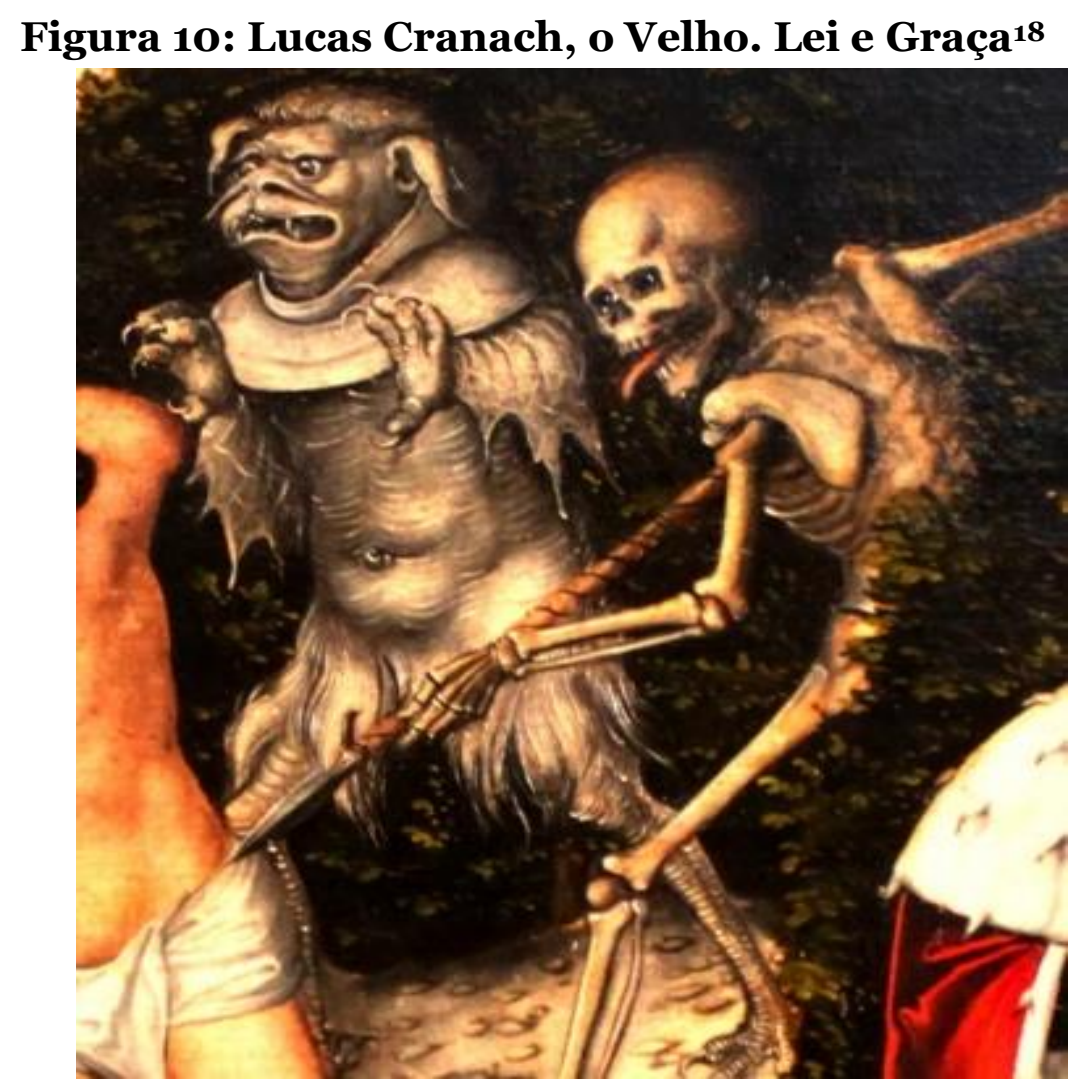

Fonte: (WIKIPEDIA, 2013).

Figura 11: A porta é apertada, o caminho é estreito (setor A-CB3) ${ }^{19}$

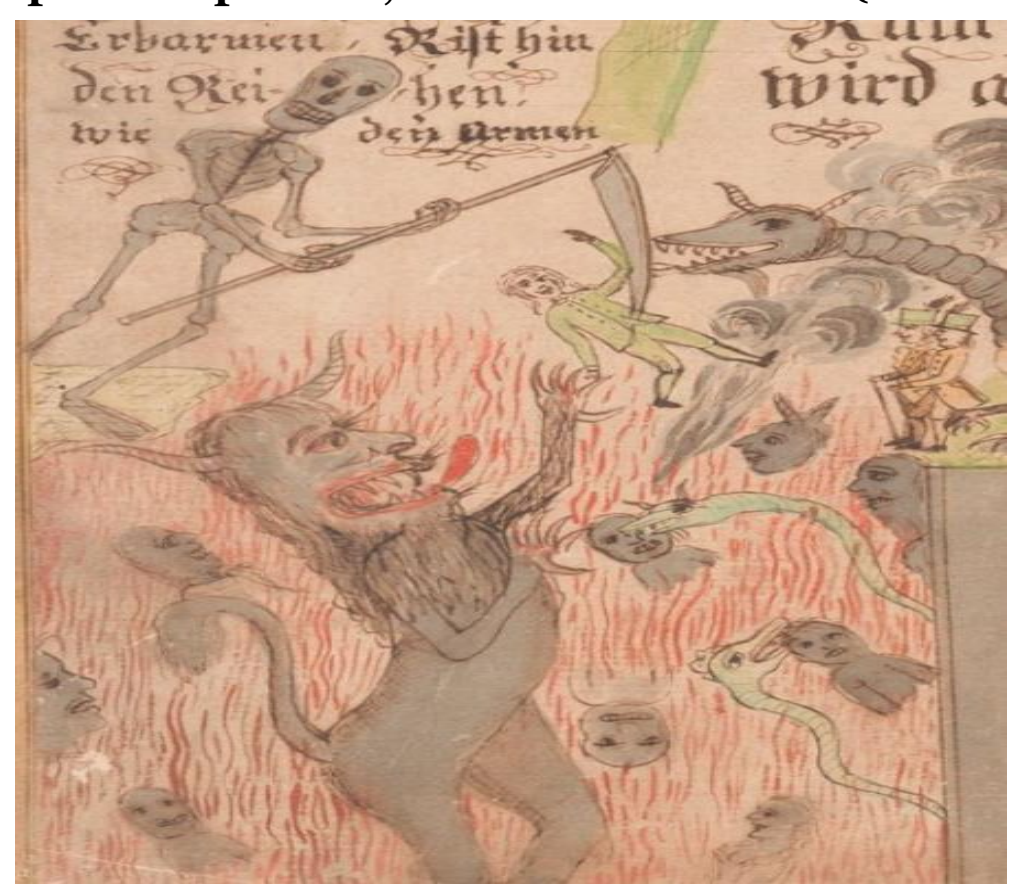

Fonte: Museu das Culturas, Basiléia, Suíça, Acervo gráfico, número VI-61756, [1800].

${ }^{18}$ Detalhe "expulsão de Adão do paraíso".

19 Detalhe "boca do inferno e morte". 
O monstro que representa a boca do inferno (figura 11), retratado abaixo da morte, lembra, pela postura em pé com as garras bestiais para a frente e pela forma da boca e as orelhas, o monstro que, com a morte, expulsa Adão do paraíso (figura 10). O desenho não aborda sua segunda aparência nos retábulos de Cranach, abaixo dos pés de Cristo (figura 11).

Figura 12: Lucas Cranach, o Velho. Lei e Evangelho'o

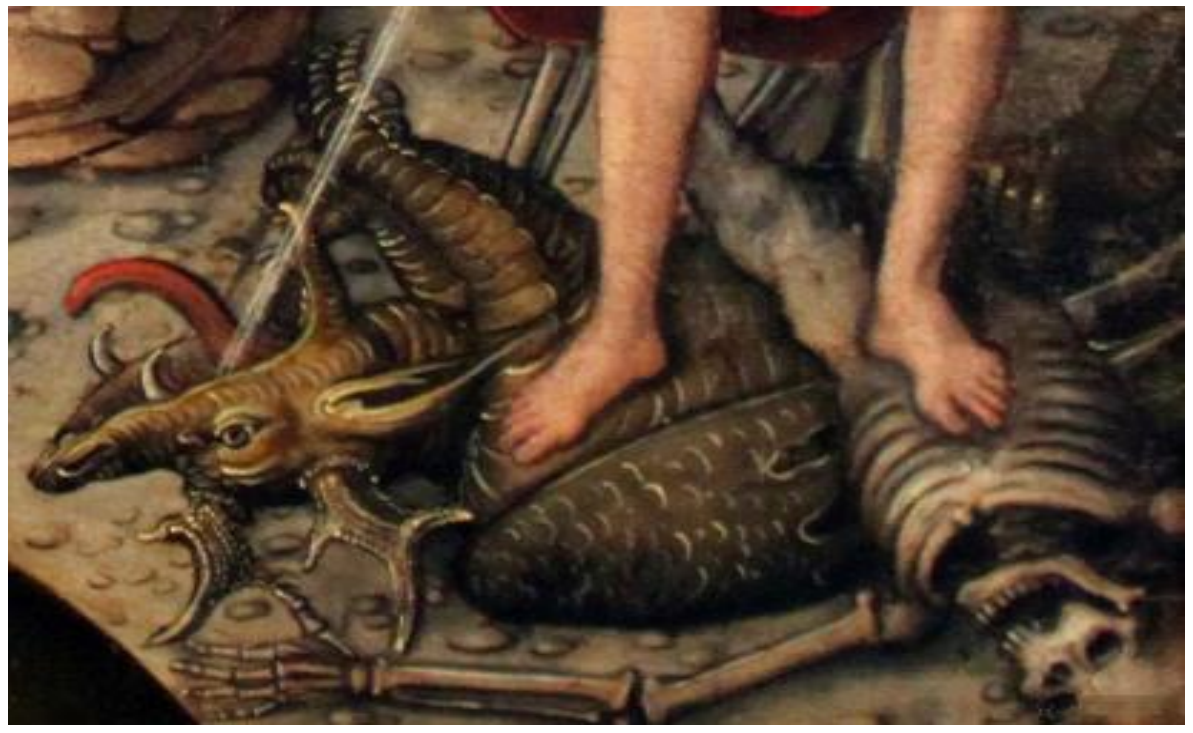

Fonte: (WIKIPEDIA, 2013).

Figura 13: A porta é apertada, o caminho é estreito (setor B1) ${ }^{21}$

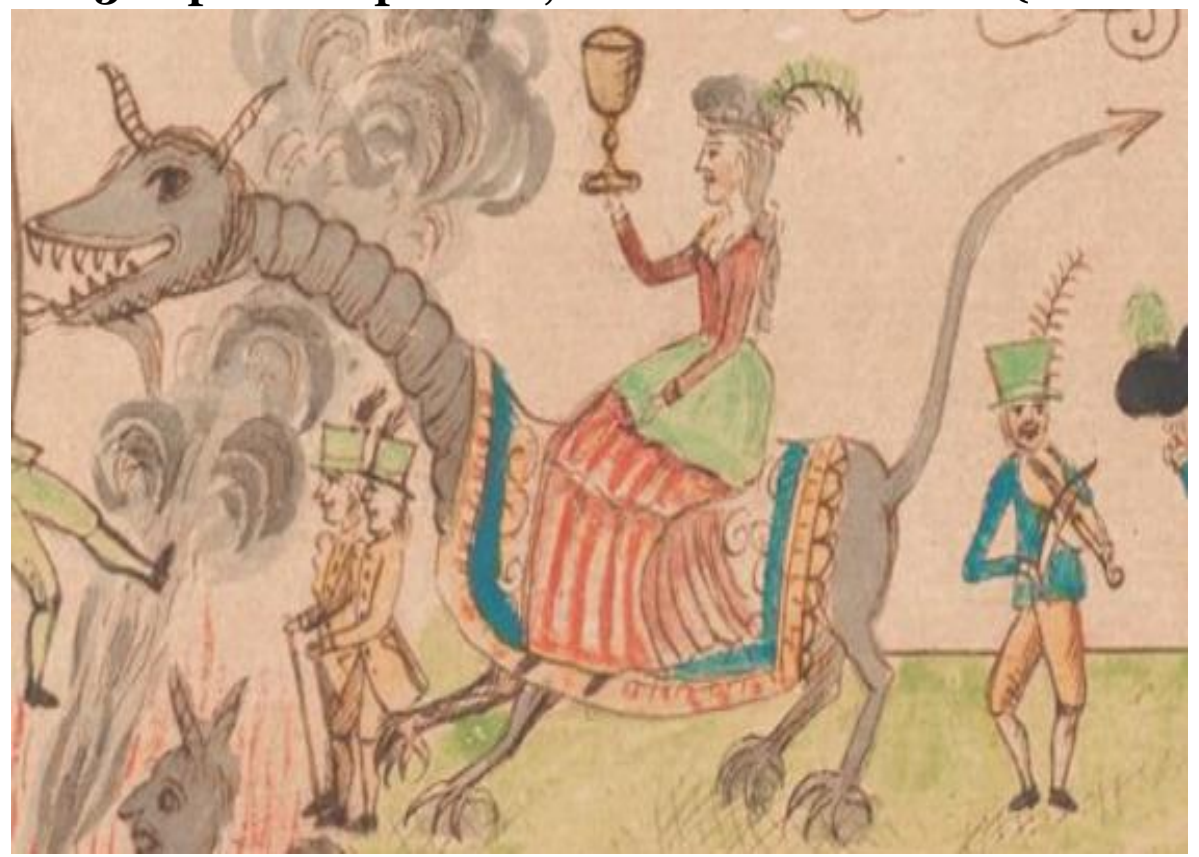

Fonte: Museu das Culturas, Basiléia, Suíça; VI-61756.

${ }^{20}$ Detalhe "a besta vencida".

${ }^{21}$ Detalhe "a prostituta Babilônia". 
Da mesma forma, o segundo motivo, a mulher acima de uma besta (figura 13), com um cálice em suas mãos, faz parte do imaginário luterano desde a época da Reforma: apesar de não aparecer nos retábulos de Cranach. Ele já se encontra como xilogravura na primeira edição do Novo Testamento na tradução de Martinho Lutero para a língua alemã de setembro 1522, também criado por Lucas Cranach como ilustração do capítulo da Revelação de João (Jo 14, 11). Além disso, lembra os detalhes da cabeça da besta de (orelhas, dentes, língua para fora) das bestas encontradas pintura de Cranach (figura 12). Ambos motivos articulam a derrota; Cranach, de forma cristocêntrica.

Ao lado oposto, na parte superior esquerda, encontramos a narrativa do paraíso (figura 15). Ela é composta de uma narrativa visual, mostrando Eva e Adão - distante um do outro - abaixo da árvore de conhecimento. Em sintonia com a narrativa bíblica original, Eva recebe a fruta, mas a narrativa textual é inclusiva e refere-se "à queda de Adão": "Enquanto a queda de Adão trouxe sobre nós a culpa e o castigo, a morte de Cristo nos libertou do sofrimento" 22 (passagem textual 2.2).

\section{Figura 14: Lucas Cranach, o mais velho. Lei e Graça23}

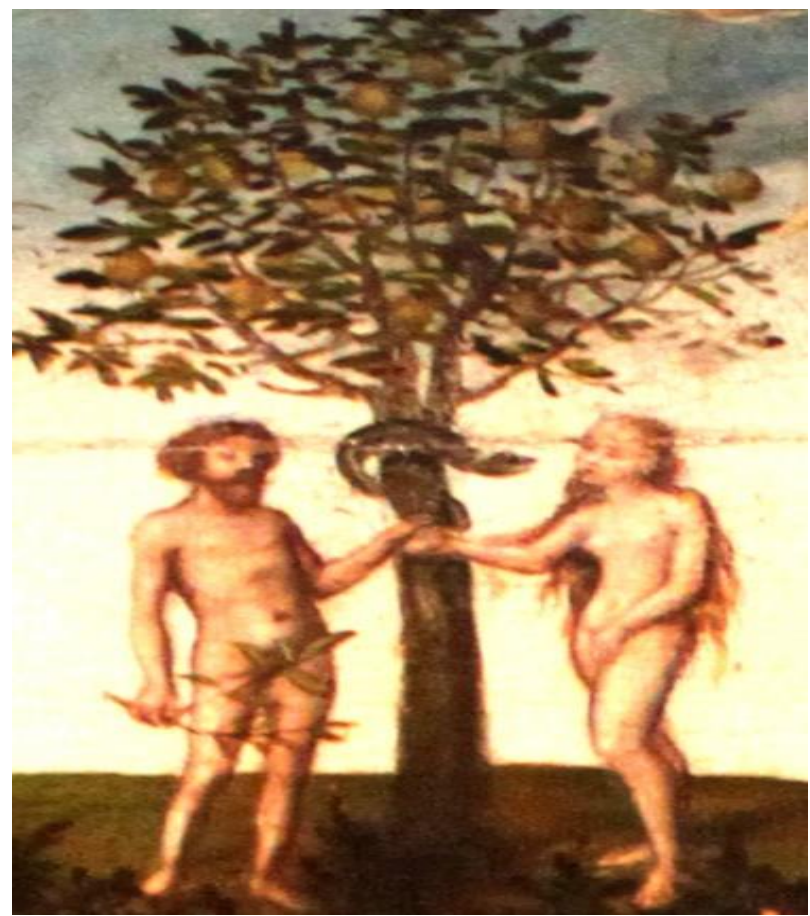

Fonte: (Wikipédia, 2013).

22 "Als Adams Fall, die Schuld und Straf, / auf uns gebracht, / so hat uns Christi Tod vom Leiden frei gemacht" . 23 Detalhe "a queda". 


\section{Figura 15: A porta é apertada, o caminho é estreito (setor B1) ${ }^{24}$}

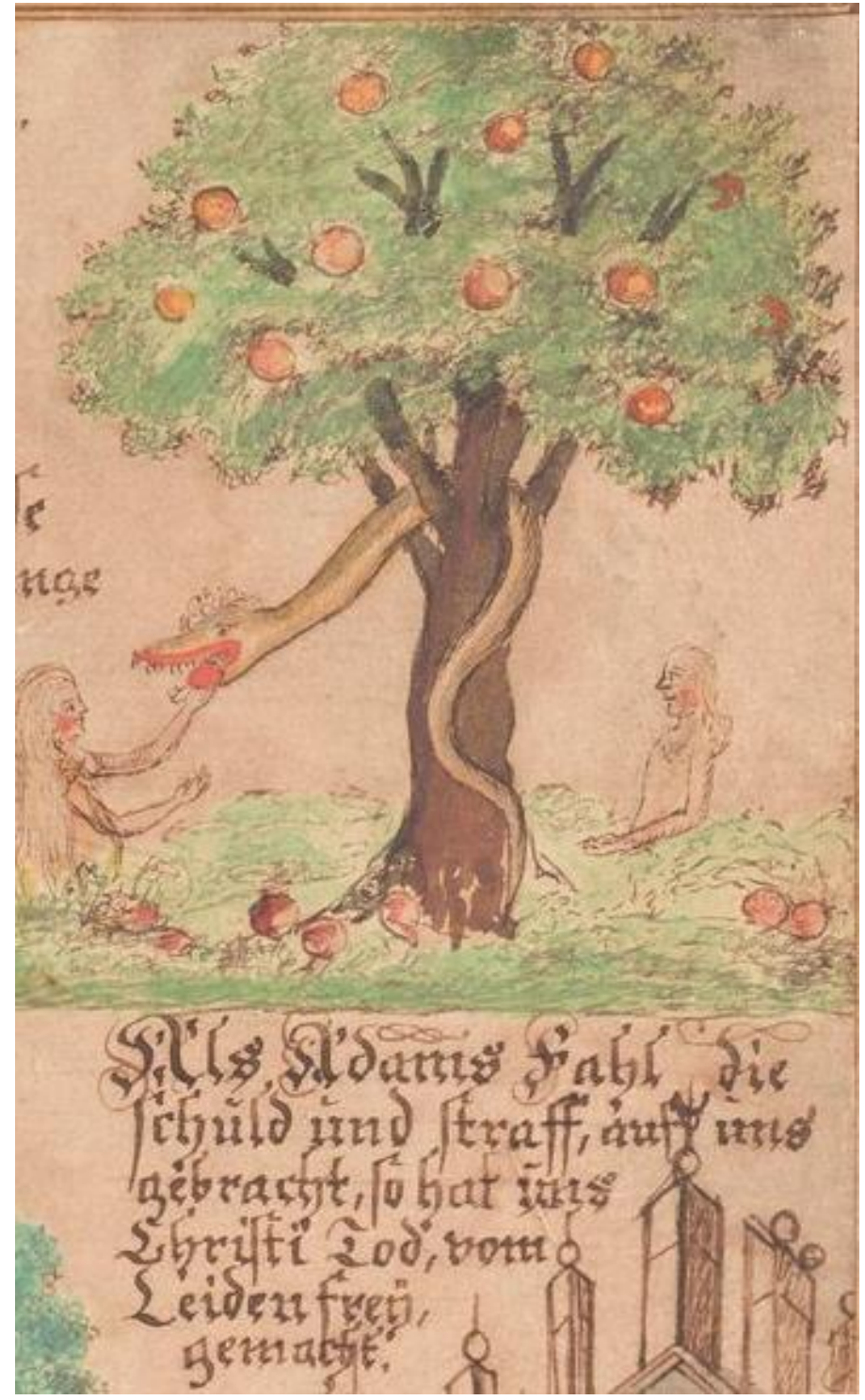

Fonte: Museu das Culturas, Basiléia, Suíça, Acervo gráfico, número VI-61756, [1800].

Trata-se de mais um detalhe compartilhado com Cranach quem nas suas pinturas Lei e Evangelho ou Lei e Graça retratou a expulsão de Adão do paraíso, mas, não da Eva. Fora disso, o desenho suíço varia Romanos 8.11 onde, originalmente, a libertação era da lrie não do sofrimento. Essa modificação do âmbito jurídico ao âmbito existencial e, ao mesmo tempo corporal ou físico e não racional, favorece a compreensão dos motivos como Pathosformeln, formas de expressar paixões [religiosas].

${ }^{24}$ Detalhe “Adão e Eva no jardim do Éden”. 


\subsection{Considerações intermediárias em relação às narrativas visuais}

Primeiro, mostra a comparação entre as obras de Cranach e o desenho de fato um Nachleben de motivos-chave da iconografia luterana. ${ }^{25} \mathrm{Em}$ seu centro está uma interpretação da cruz de Cristo como sinal do amor divino irrestrito para com o mundo, construído pela referência dupla à serpente erguida por Moisés e à crucificação de Jesus como porta ao céu. Segundo, pode-se dizer que os motivos escolhidos são cheios de pathos, lágrimas e alegrias. A linguagem visual é afetiva, enquanto articula uma intensa relação entre Deus e a humanidade, entre os seres humanos e Deus, no sentido de articular essa relação mútua de forma emotiva e dramática. Refere-se à grande possiblidade de desencontros, à remota possibilidade de um encontro e final feliz. Mencionase sofrimento divino e humano ao lado da hibris humana, das escolhas humanas, supostamente errôneas ou certas. Desenham-se o céu e a boca do inferno, e nos caminhos pessoas em movimento, indo para um lugar do sonho ou da angústia. O retrato das próprias pessoas, carregando a própria cruz ou riquezas, dançando, jogando cartas e fumando. É igualmente o retrato de seres cheios de emoções e de planos, inclusive, se for a busca de diversão ou entretenimento. São retratos de seres apaixonados/as que se procura alcançar por uma linguagem visual impactante, comovente e performativa, pelo uso de motivos cristãos gerais e, ao mesmo tempo, reafirmados pela tradição luterana, usando motivos da obra de Lucas Cranach do século 16 como referência, criando, dessa forma, um Nachleben dos seus motivos principais.

\section{Nachleben e Pathosformeln nas narrativas textuais do desenho}

Nessa segunda parte, focamos mais nas narrativas textuais do desenho que acompanham suas narrativas visuais. Nosso objetivo é verificar em que sentido eles podem ser considerados Pathosformeln metafóricos. Para facilitar a orientação, interpretamos essas passagens textuais na base da distinção anterior, considerando ainda o título:

\footnotetext{
${ }_{25}$ Todavia, nem tudo se encaixa nisso de forma perfeita. A representação do Cristo Rei, que recebe as cinco mulheres no portal da Nova Jerusalém, não encontra nenhum correspondente nas obras de Cranach. Embora Cranach, o Velho, faça antes de 1517 diversas pinturas da Trindade e do Trono da Graça, em que aparece sempre como figura real Deus Pai com uma coroa e um manto, não há nada equivalente em relação a Cristo.
} 


\section{Figura 16: A porta é apertada, o caminho é estreito: Distribuição e} vinculação de textos que acompanham

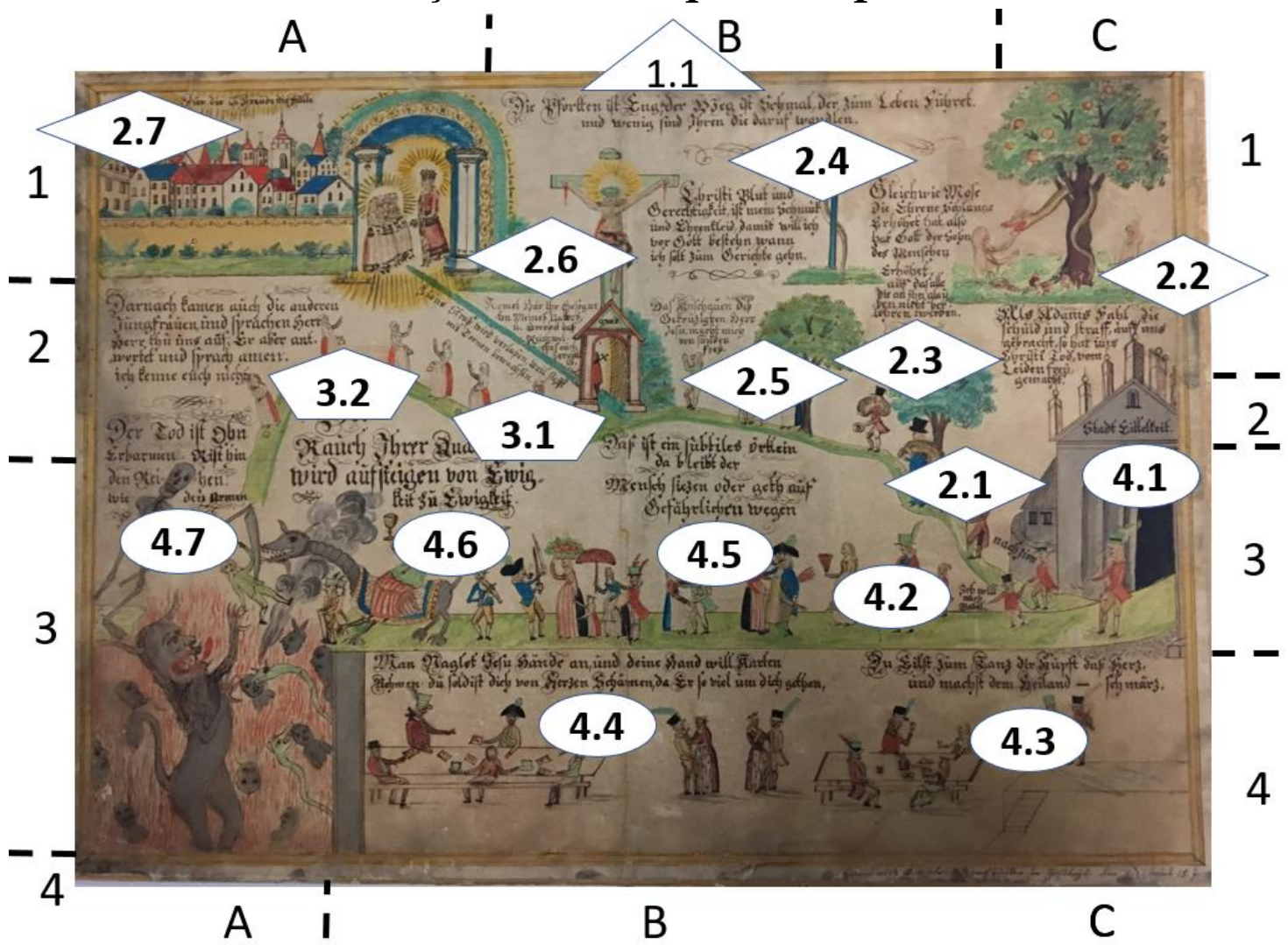

Fonte: Museu das Culturas, Basiléia, Suíça, Acervo gráfico, número VI-61756,

[180o].

a) Título (seção B1, passagem textual 1.1);

b) Um caminho muito estreito que, literalmente, passa pela cruz à Nova Jerusalém (seção 1B, 2.1 à 2.7);

c) O caminho estreito que passa somente por perto da cruz e de lá para a morte (seções 2A-C, 3.1 à 3.2),

d) O caminho largo que leva diretamente da cidade da vaidade ao inferno (seções 3A-C, passagens textuais 4.1 à 4.7).

O aspecto afetivo da vida religiosa já transparece no "tom" do próprio título do desenho (passagem de texto 1.1). A citação de Mateus 7.14 - "Estreita é a porta, e apertado, o caminho que leva à vida, e poucos há que a encontrem" (Mt 7, 14, tradução nossa). ${ }^{26}$ - é uma alerta que o ser humano pode se perder ou "não encontrar" o caminho para o céu.

${ }^{26}$ Wie eng ist die Pforte und wie schmal der Weg, der zum Leben führt, und wenige sind's, die ihn finden! 


\subsection{Um caminho muito estreito que, literalmente, passa pela cruz à Nova Jerusalém (seção 1B)}

O aspecto afetivo passa, além pela escolha do estilo das narrativas (metafórico), pelas formas que conduzem a pessoa a um envolvimento e a interação maior (canções e orações). As passagens referentes ao caminho estreito que se encontram nos setores C2 (passagens de texto 2.1 e 2.2), C1 (passagens de texto 2.3 e 2,5), B1 (passagens de texto 2.4 e 2.6) e A1 (passagem de texto 2.7) formam uma diagonal em cujo início se encontra a intenção (2.1) que leva a uma felicidade que simplesmente transborda (passagem de texto 2.7). Conforme já nos referimos às passagens textuais 2.2 e 2.3 em outro lugar, começamos com o texto ao lado esquerdo abaixo do crucifixo: "O sangue e a justiça de Cristo, / Minha joia e meu vestido de honra, / pelos quais eu permanecerei diante de Deus, / quando me apresentarei ao juízo final” (MUSEU DAS CULTURAS, VI-61756, tradução nossa). ${ }^{27}$ (2.4), trata-se de uma citação de uma canção luterana. Já ao lado esquerdo do crucifixo, na altura da entrada abaixo dele, encontramos uma oração contemplativa: "Contemplar Jesus, o Senhor crucificado, / me liberta dos pecados. " (MUSEU DAS CULTURAS, VI61756, tradução nossa). ${ }^{28}$ Contemplar é certamente mais do campo da espiritualidade romana. As passagens 2.2 até 2.5 (Romanos 8.11 (passagem de texto 2.2), João 3.14-16 (passagem de texto 2.3), a primeira estrofe da canção Christi Blut und Gerechtigkeit (Cristo Sangue e Justiça) de Zinzendorf (passagem de texto 2.4) focam a força performativa e salvífica da morte na cruz (passagem textual 2.2), na cruz como sinal de amor de Deus (passagem textual 2.3), na fidelidade de Deus como garantia da permanência na sua proximidade (passagem textual 2.4), na cruz como sinal da libertação (passagem textual 2.5) e no reino como preparado para seus herdeiros. Todas essas passagens textuais são reafirmadas por aspectos visuais. $\mathrm{O}$ tom dessas passagens é esperançoso: o acento está nos fundamentos da salvação. Quanto ao texto, há pequenas variações: Romanos (Ro 8, 11) fala da libertação da lei, o nosso desenho da libertação do sofrimento e João fala de "ter a vida eterna" (Jo 3, 14-16), enquanto nosso desenho expressa a esperança de "não se perder”. Ao final do

\footnotetext{
${ }^{27}$ Christi Blut und Gerechtigkeit, / Mein Schmuck und Ehrenkleid, / Damit will ich vor Gott bestehen, / Wann ich sollt zum Gerichte gehn.

${ }^{28}$ Kommt her ihr gesegneten meines Vaters. Ererbet das Reich welches euch bereitet.
} 
caminho, acima da cidade, encontramos uma citação do Salmo 16.11: "Diante de ti há alegria na abundância” (Sl 16, 11, tradução nossa). ${ }^{29}$ Mais uma vez se trata de referências carregadas de paixões e emoções, inclusive o fato que os Salmos são orações usadas nos cultos.

\subsection{O caminho estreito que passa somente por perto da cruz e de lá para a morte (seções $2 \mathrm{~A}-\mathrm{C}$ )}

Segundo a litografia, mesmo quem anda incialmente bem, pode perderse. "A estrada de Sião é abandonada porque nela sempre crescem espinhos." (MUSEU DAS CULTURAS, VI-61756, tradução nossa). $3^{\circ}$ (passagem textual 3.1) e as portas do céu podem ficar fechadas: "Então vieram as outras virgens, dizendo: Senhor, Senhor, abra-nos. E ele respondeu e disse: Amém, eu não conheço vocês.” (Mt 25, 12, tradução nossa).31 (passagem textual 3.2).

\subsection{O caminho largo que leva diretamente da cidade da vaidade ao inferno (seções 3A-C)}

$\mathrm{Na}$ descrição do caminho largo, usam-se recursos textuais parecidos. O ponto de partida é novamente a "cidade da vaidade" (MUSEU DAS CULTURAS, VI-61756, tradução nossa). ${ }^{2}$ Trata-se de um motivo do décimo terceiro capítulo do livro O peregrino (1678) de Bunyan, uma referência reformada e um clássico da literatura devocional protestante33, que afirma que o caminho do peregrino para o Sião passa pela "cidade da vaidade" 34. Abaixo do caminho largo, encontramos ao redor de duas mesas soldados e mulheres, bebendo e jogando cartas. As duas passagens textuais (4.3 e 4.4) relacionadas a essa cena citam a canção "A criança do mundo que todos desejam. " (FLEISCHBAUER, 1681, p. 268; tradução nossa). 35 A passagem 4.3 cita a quarta estrofe: "Você se apressa para a dança, o seu coração pula [de alegria] e causa a dor ao seu salvador”

\footnotetext{
${ }_{29}$ Du tust mir kund den Weg zum Leben:] Vor Dir ist Freude die Fülle [und Wonne zu deiner Rechten ewiglich.

30 Zions Straße wird verlassen, weil stets mit Dornen bewachsen.

${ }^{31}$ Danach kamen auch die anderen Jungfrauen und sprachen: Herr, Herr, tu uns auf! Er aber antwortete und sprach:

Amen, ich kenne euch nicht.

$3^{2}$ Stadt der Eitelkeit.

33 Bunyon não era luterano, mas, um puritano inglês que se tornou ao fim da sua vida batista.

34 Da nun Beelzebub, Apollyon und Legion mit ihren Genossen an dem Pfade, den die Pilger gingen, es merkten, daß

ihr Weg nach Zion durch die Stadt Eitelkeit. Confere a primeira edição em alemão John Bunyon (1685)

$35 \mathrm{Du}$ Kind der Welt! das alle Lust.
} 
(FLEISCHBAUER, 1681, p. 269; tradução nossa). ${ }^{36} \mathrm{Na}$ última linha, aparece ainda o motivo do caminho largo (breite Bahn) e na segunda linha da quinta estrofe da mesma canção, o motivo do "caminho tão estreito para o céu" (FLEISCHBAUER, 1681, p. 269; tradução nossa) 37 (schmalen Himmelswege) ou do caminho da vida tão apertado (schmalen Lebenstege). Na segunda linha da sexta estrofe da mesma canção, encontramos ainda uma referência à diversão de jogar cartas, motivo retratado no desenho: "Você joga e não pensa na morte, / [mas], ele vê as suas cartas. " (FLEISCHBAUER, 1681, p. 269; tradução nossa) ${ }^{38}$, ou seja, a morte joga de forma desonesta.

Acima do motivo da segunda mesa do lado esquerdo, encontra-se uma segunda citação direta dessa canção (passagem de texto 4.4): “As mãos de Jesus foram pregadas [na cruz], e sua mão quer pegar cartas, / E você deveria se envergonhar nas profundezas do seu coração, já que Ele fez tanto por você. ” (FLEISCHBAUER, 1681, p. 269. Tradução nossa). 39 A canção é de Johann Ludwig Konrad Allendorf (1748, cancão n. 143). Allendorf (1693-1773) estudou com o pietista August Herman Franke (1663-1727) e era um pedagogo, pastor e compositor de hinos religiosos luteranos.

Já nas passagens textuais acima do caminho largo, encontramos em seu início um alerta geral - "Aquilo é um lugarzinho sutil, onde fica parado / o ser humano ou anda em caminhos perigosos.” (MUSEU DAS CULTURAS, VI61756, tradução nossa) 40 (passagem textual 4.5) - e depois (passagem textual 4.6) um alerta radical baseiado na Revelação de João 14,11: "A fumaça do seu tormento sobe pelos séculos dos séculos. " (Jo 14,11, tradução nossa). ${ }^{41} \mathrm{O}$ capítulo 14 contém o motivo da cidade da Babilônia como prostituta (14.8), que a litografia retrata como mulher em cima de uma besta (MUSEU DAS CULTURAS, VI-61756, tradução nossa). Finalmente, lê-se acima da boca do

\footnotetext{
${ }^{36}$ Du eilst zum Tanz, dir hüpft das Herz, / [Und springst mit deinen leichten Füseen: / Imdessen muß dein Heiland büseen: / Du lachst und er empfindet] Schmerz. [/ Er läßt die Füsse sich durchbohren, / Die keinen bösen Tritt gerhan: / Do folgst dem Tact mit Fuß und Ohren / So hurtig auf der breiten Bahn.

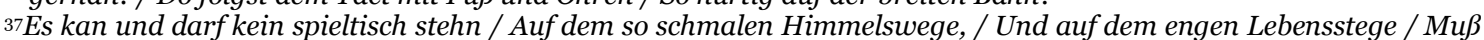
man mit fachten Schritten gehn. / Muste, die nicht zu Gottes shren, / Und nur zur Uppigkeit erklingt, / Dient edle Stunden zu verzehren, / Die kein Bereuen wiederbringt.

${ }_{38}^{8} \mathrm{Du}$ spielst und denkst nicht an den Tod, / Er sieht dir gleichsam in die Karten; / Er schleicht dir nach, auf dich zu warten, / Wenn du von tanzen warm und roth./ Wie flöt und geigen klang im Winde / Sich durch die weite Luft zerstreut; Ach! denke eben so geschwinde / Verschwindet deine ledenszeit"

39 Man nagelt Jesu Hände an, / und deine Hand will Karten nehmen, / Und solltest dich von Herzen schämen, / da er soviel für dich getan.

${ }^{40}$ Das ist ein subtiles Örtlein, / da bleibt der / Mensch siezen [sitzen, o autor] oder geht auf / gefährlichen Wegen.

${ }^{41}$ Der Rauch ihrer Qual wird aufsteigen von Ewigkeit zu Ewigkeit.
} 
inferno e ao lado da representação da morte "A morte é sem piedade, / Leva consigo o rico e o pobre” MUSEU DAS CULTURAS, VI-61756, tradução nossa) 42 (passagem textual 4.7).

\subsection{Considerações intermediárias em relação às narrativas textuais}

Tanto o caminho estreito como o caminho largo são acompanhados por referências a orações, guias devocionais, hinos e textos bíblicos. O fato de que se citam hinos de dois importantes compositores das vertentes pietistas de Halle e de Herrenhut, combina com um dos resultados da análise visual: a litografia reflete um contexto luterano. Além disso, promove já a ênfase na hinologia, entretanto ainda muito mais pela escolha de canções pietistas, uma forma afetiva das práticas religiosas. Hinos pietistas são complexas e múltiplas Pathosformeln em termos estruturais e formais43. O mesmo vale pela escolha de guias devocionais - mesmo que a referência ao livro $O$ peregrino (1674) de Bunyan seja mais sutil - e de textos bíblicos que no ambiente luterano e especialmente pietista não eram somente lidos nos cultos públicos, mas também nos encontros entre leigos/as e durante práticas devocionais pessoais, particulares ou nas famílias. Ler o texto sagrado, seguir guias espirituais, cantar juntos são práticas religiosas que carregam e descarregam paixões e afetos.

\section{Considerações finais}

Sem conhecer a gravura original que servia como base para esse desenho, ou seja, sem a oportunidade de fazer uma comparação direta entre o suposto original e o desenho, não podemos dizer com exatidão até que ponto esse desenho é mais uma cópia fiel ou um resultado de um processo mais criativo. No máximo, podemos fazer o caminho inverso e comparar o desenho com obras posteriores parecidas, por exemplo, as xilogravuras francesas de Georgin. Em todas essas obras, o motivo da Nova Jerusalém ocupa toda a faixa superior do desenho. As referências ao paraíso, a serpente erguida por Moisés como também o retrato das duas mesas com os soldados e as mulheres ao redor jogando cartas e bebendo não existem. Tampouco se encontram as referências à

${ }^{2}$ Der Tod ist ohn[e] Erbarmen, nimmt hin den Reichen und den Armen.

${ }_{43}$ De fato, Nietsche $(1780, \S 1)$ relaciona a música com o aspecto dionisíaco da vida e se refere ao "tremendo poder do tom". 
hinologia luterana ou pietista. Em alguns detalhes, a originalidade é muito provável, como a escolha de retratar os soldados com uniformes suíços. A comparação de xilogravuras ou litografias com o tema dos dois caminhos, como por exemplo de Georgin e Reihlen, mostram que a regra era a adaptação de uniformes às fardas do país onde a obra foi lançada. Os uniformes ajudam, portanto, na identificação do grupo-alvo e não correspondem, especificamente, a uma versão anterior (Cf. RENDERS, 2018).

"Nova Jerusalém”, “crucifixo”, "boca do inferno”, "paraíso”, “árvore da vida", "caminho largo e caminho estreito", são metáforas essenciais da fé cristã desde a Antiguidade. Enquanto as metáforas no texto são auto evidentes e facilmente identificadas, narrativas visuais requerem ou o suporte pela reprodução de atributos específicos - o que resulta, por exemplo, na identificação de um retrato de um crucificado como Cristo crucificado -, ou a combinação de diversos motivos cristãos - como nas obras de Lucas Cranach o Velho e o Jovem e na obra aqui estudada. Assim, no caso da cultura visual religiosa cristã, especialmente, da sua arte devocional, não é um elemento específico e único que serve para a sua identificação, como seria o caso da ênfase de Aby Warburg no aspecto dionisíaco quanto à arte pagã. Apesar de considerarmos a proposta de Warburg como um reducionismo - também a arte pré-cristã tem mais aspectos e funções -, é interessante que os motivos religiosos sem atribuições ou agrupamentos específicos não se comuniquem como "religiosos". A primeira razão deve ser porque esses motivos são, em sua maioria, parte do cotidiano da vida humana, com vinho, mesa, pão, cidade, árvore, caminho, luz etc. e é o conjunto desses motivos cotidianos cujos Nachleben informam para instruir e performam para comover em termos religiosos.

Assim, a força performática da arte visual religiosa ou o seu Nachleben se instala pelo conjunto de motivos, e isso tanto mais quanto mais motivos identificáveis se unem. Como resultado, é o conjunto de motivos como "paraíso", “expulsão do paraíso”, “dez mandamentos”, "crucifixo”, "Nova 
Jerusalém" e "Árvore da vida" 44 que ganha força performativa e se transforma em apelo e impulso religioso que um texto racional jamais teria. $\mathrm{O}$ aspecto do Nachleben desses motivos como Pathosformeln é, de fato, fundamental para cumprir seu papel e sua vocação de orientação devocional de conduzir o ser humano aos caminhos da fé. O aspecto, ou melhor, o fenômeno do Nachleben explica e descreve o aspecto vital de narrativas visuais e metafóricas de uma tradição religiosa.

\section{REFERÊNCIAS}

AGAMBEN, Giorgio. Aby Warburg and the Nameless Science. In: HELLER-ROAZEN, Daniel (ed.). Potentialities: Collected Essays in Philosophy. Stanford: Stanford University Press, 1999. p. 89-103.

\section{ALLENDROF, Johann Ludwig Konrad. Die Cöthnischen Lieder zum Lobe des dreyeinigen Gottes und zu gewünschter ereicher Erbauung vieler Menschen. Mit Inhalts- und Anfangsregistern herausgegeben. Vermehret mit einem Anhang einiger Fest-Gesängen des Herrn Grafen von Stollberk Wernigerode. Cöthen Schöndorf, 1748.}

BECKER, Colleen. Aby Warburg's Pathosformel as methodological paradigm. Journal of Art Historiography, Bermingham, v. 9, p. 1-25, 2013.

BREDEKAMP, Horst. Teoria do acto icónico. Tradução de Artur Morão. Lisboa: KKYM, 2015.

BUNYAN, John. Eines Christen Reise nach der seeligen Ewigkeit. Welche in unterschiedlichen artigen Sinnen-Bildern Den gantzen Zustand einer Bußfertigen und Gottsuchenden Seelen vorstellet. Hamburg: Wolff, 1685.

BURUCÚA, José Emilio. Historia, arte, cultura: de Aby Warburg a Carlo Ginzburg. Buenos Aires: Fondo de Cultura Económica, 2003.

DIDI-HUBERMAN, Georges. A imagem sobrevivente: história da arte e tempo dos fantasmas segundo Aby Warburg. Tradução de Vera Ribeiro. Rio de Janeiro:

Contraponto, 2013.

\section{FLEISCHBAUER, Johann Georg. Der Cöthnischen Lieder Erster und Anderer}

Theil: zum Lobe Gottes des dreieinigen Gottes. Reutlingen: 1689.

HIPÓLITO, Rodrigo; PEDRONI, Fabiana. A visão de Didi-Huberman sobre Warburg e a contribuição do retorno à "ciência sem nome" para o tratamento com a arte contemporânea. Art\&Sensorium: revista interdisciplinar e internacional de artes visuais, Curitiba, v. 4, n. 2, p. 242-254, jul.- dez. 2017.

44 A combinação pode variar: Lucas Cranach usava tanto nos seus retábulos como nos quadros

Lei e Evangelho e Lei e Graça o conjunto dos motivos da tentação de Adão e Eva, a expulsão do paraíso, os dez mandamentos, o crucifixo, a ressurreição. 
MORGAN, David. The Ecology of Images: Seeing and the Study of Religion. Religion and Society: Advances in Research, v. 5, n. 83-105, 2014.

NIETSCHE, Fridrich Wilhelm. Die dionysische Weltanschauung, 1870. In: COLLI, Giorgio; MONTINARI, Mazzino (ed.). Digitale Kritische Gesamtausgabe Werke und Briefe auf der Grundlage der Kritischen Gesamtausgabe Werke. Berlin: Walter de Gruyter, 1967. Disponível em: http://www.nietzschesource.org/\#eKGWB/DW. Acesso em: 20 maio 2018.

SCHAPIRO, Meyer. Estudios sobre el arte de la Antiguedad Tardia, el Cristianismo Primitivo y la Edad Media. Madrid: Aliana Editorial, 1987.

SCHAPIRO, Meyer. Estudios sobre el Romanica. Madrid: Aliana Editorial, 1984.

SCHMIDT, Gary D. The iconography of the Mouth of hell: eighth-century Britain to the fifteenth century. Selinsgrove, PA: Susquehanna University Press; Cranbury, NJ: Associated University Presses, 1995.

SERVA, Leão. A "fórmula da emoção" na fotografia de guerra: como as imagens de conflitos se relacionam com a tradição iconográfica explorada por Aby Warburg. 2017. Tese (Doutorado em Comunicação e Semiótica) -Pontifícia Universidade Católica de São Paulo, São Paulo, 2017.

SERVA, Leão. Caveiras: um 'Pathosformel' da Fotografia de Guerra. Anais da Intercom. XXXVIII Congresso Brasileiro de Ciências da Comunicação - Rio de Janeiro, RJ - 4 a 7/9/2015. Disponível em:

http://portalintercom.org.br/anais/nacional2015/resumos/R10-3079-1.pdf . Acesso em: 5 maio 2018.

SOCIEDADE BÍBLLICA DO BRASIL. Bíblia de Estudos John Wesley. Barueri, SP: 2019.

WIKIPÉDIA, l'encyclopédie libre. Fichier: 1529, Cranach Allegorie auf Gesetz und Gnade. 2013. Disponível em:

https://upload.wikimedia.org/wikipedia/commons/c/cb/1529_Cranach_Allegorie_auf _Gesetz_und_Gnade_anagoria.JPG. Acesso em: 5 maio 2018. 


\section{Anexo 1: S.N. A porta é apertada, o caminho é estreito (setor B1)}

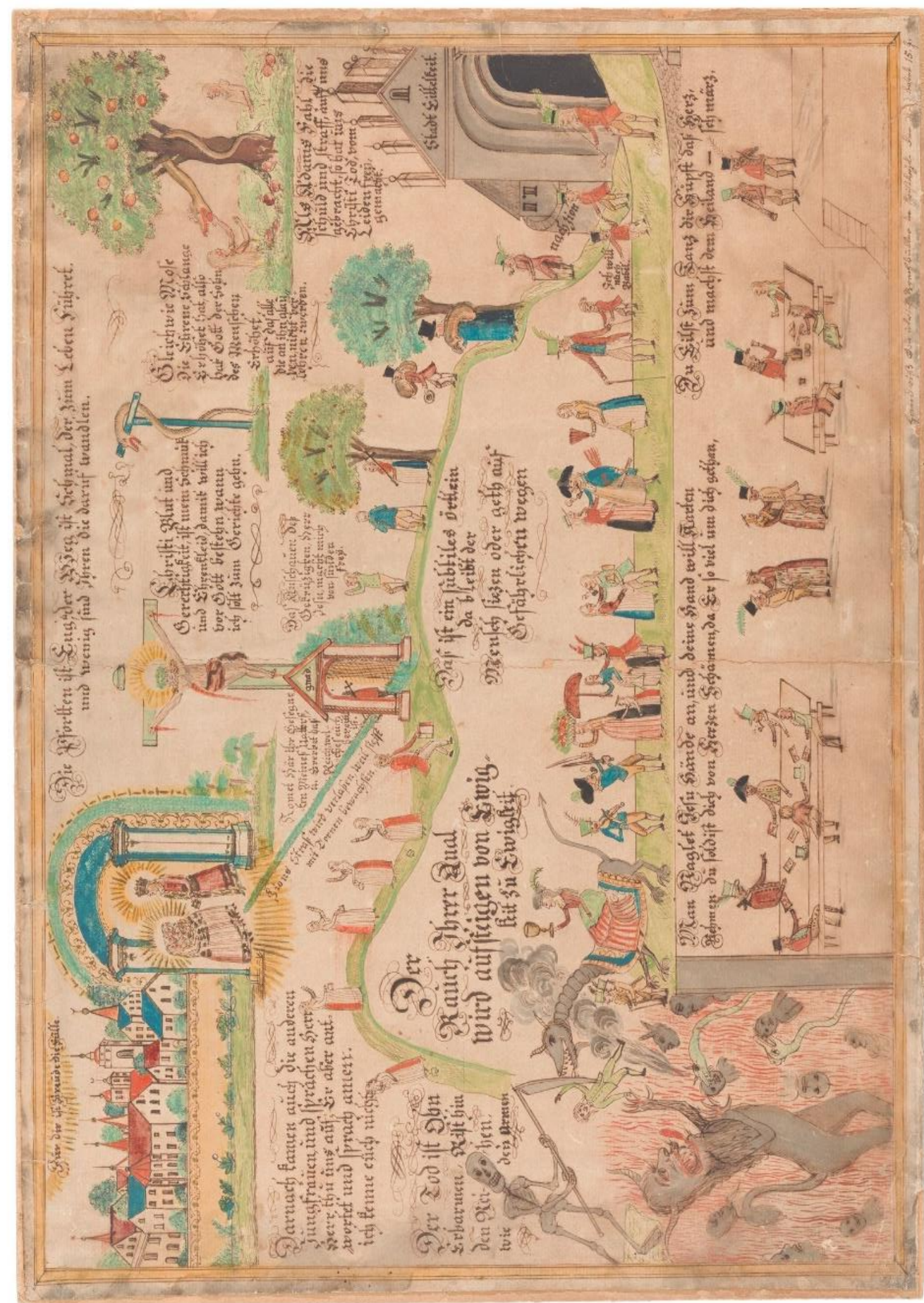

Museu das Culturas, Basiléia, Suíça, Acervo gráfico, número VI-61756, [180o]. 